\title{
Survival and growth responses of snakehead fish Channa striata Bloch juvenile in aerated and unaerated acid sulfate water
}

\author{
Respons kelangsungan hidup dan pertumbuhan juvenil ikan gabus \\ Channa striata Bloch pada air rawa pasang surut dengan dan tanpa aerasi
}

\author{
Purnamawati $^{1,2 *}$, Daniel Djokosetiyanto ${ }^{1}$, Kukuh Nirmala $^{1}$, Enang Harris Surawidjaja ${ }^{1}$, \\ Ridwan Affandi ${ }^{3}$ \\ ${ }^{1}$ Departemen Budidaya Perairan, Fakultas Perikanan dan Ilmu Kelautan, Institut Pertanian Bogor \\ Jalan Agatis, Kampus IPB Dramaga, Bogor 16680 \\ ${ }^{2}$ Program Studi Budidaya Perikanan, Politeknik Negeri Pontianak \\ Jalan Ahmad Yani, Bansir Laut, Pontianak Tenggara, Kota Pontianak 78124 \\ ${ }^{3}$ Departemen Manajemen Sumberdaya Perairan, Fakultas Perikanan dan Ilmu Kelautan, Institut Pertanian Bogor \\ Jalan Agatis, Kampus IPB Dramaga, Bogor 16680 \\ *E-mail: Pur_polnep@yahoo.com
}

\begin{abstract}
The aim of the research was to analyze survival, specific growth rate, albumin, feed efficiency and physiological (blood glucose, cortisol, dan haemoglobin) responses of snake head fish juvenil reared in aerated and unaerated of tidal land water have been conducted in the laboratory. An experiments using completely randomized design with aerated and unaerated as a treatment, and each treatment has twelve replications. The snakehead fish juvenil wich length $2.4 \pm 0.2 \mathrm{~cm}$ and weight of $0.21 \pm 0.05 \mathrm{~g}$ reared in the aquarium that are size $30 \times 25 \times 35 \mathrm{~cm}$ (water volume $25 \mathrm{~L}$ ) with a stocking density 2 juvenile/L, for 40 days. The fishes were fed with commercial feed with protein content about $40 \%$, feeding two times a day (morning and afternoon) were at satiation. Replacement of water done every two days about $10 \%$ of the total water volume in the aquarium. The results showed that unaerated median significantly affected to biometric and physiological response of juvenile of snake head fish. The media un-aerated gives the best results shown by the higher value of survival (92\%), specific growth rate (6.73\%/day), feed efficiency $(78.22 \%)$, protein retention (41.91\%), energy retention (30.81\%) value of albumin $(6.60 \mathrm{~g} / 100$ $\mathrm{mL})$ and the haemoglobin $(5.58 \mathrm{~g} / \mathrm{dL})$, and have the lowest value of cortisol $(21.49 \mathrm{ng} / \mathrm{L})$ and blood glucose $(43.36$ $\mathrm{mg} / 100 \mathrm{~mL})$.
\end{abstract}

Keywords: acid sulfate water, growth rate, aeration, Channa striata

\begin{abstract}
ABSTRAK
Penelitian ini bertujuan untuk menganalisis respons kelangsungan hidup, pertumbuhan spesifik, kadar albumin, dan efisiensi pakan dan fisiologis (kortisol, glukosa darah, dan hemoglobin) juvenil ikan gabus yang dipelihara dengan dan tanpa aerasi pada media air rawa pasang surut. Penelitian menggunakan rancangan acak lengkap dengan aerasi dan tanpa aerasi sebagai perlakuan, dan masing-masing perlakuan memiliki 12 ulangan. Juvenil ikan gabus berukuran panjang $2,4 \pm 0,3 \mathrm{~cm}$ dan bobot $0,21 \pm 0,03 \mathrm{~g}$ dipelihara dalam akuarium $30 \times 25 \times 35 \mathrm{~cm}$ (volume 25 L) dengan padat tebar 2 ekor/L, selama 40 hari. Ikan diberi pakan berupa pakan komersial dengan kadar protein $\pm 40 \%$, pemberian pakan dua kali sehari (pagi dan sore) at satiation. Penggantian air dan penyiponan dilakukan dua hari sekali sebanyak 10\% dari volume total dalam akuarium. Hasil penelitian menunjukkan bahwa perlakuan tanpa aerasi berpengaruh nyata terhadap respons biometrik dan fisiologis juvenil ikan gabus. Media tanpa aerasi memberikan hasil yang lebih baik ditunjukkan oleh kelangsungan hidup (92\%), laju pertumbuhan spesifik $(6,73 \%$ / hari), efisiensi pakan (78,22\%), retensi protein (41,91\%), retensi energi (30,81\%), kadar albumin $(6,60 \mathrm{~g} / 100 \mathrm{~mL})$, dan hemoglobin $(5,85 \mathrm{~g} / \mathrm{dL})$ yang lebih tinggi, sedangkan kadar kortisol (219 ng/L) dan glukosa darah (43,36 $\mathrm{mg} / 100 \mathrm{~mL}$ ) yang terendah.
\end{abstract}

Kata kunci: aerasi, Channa striata, media sulfat masam, pertumbuhan 


\section{INTRODUCTION}

The low productivity of fisheries commodities in acid sulfate areas is caused by several problems, especially poor water quality, including low dissolved oxygen level (less than $5 \mathrm{mg} / \mathrm{L}$ ), high acidity ( $\mathrm{pH} 3-5)$ and the intrusion of sea water that makes the water becoming brackish. With these suboptimal mediums, not all fish species can be reared in these areas. To determine the commodities which can survive in the acid sulfate water conditions, can be applied several criteria, including tolerance to environmental fluctuations, high survival, and growth (El-Sayeed et al., 1996). Based on these criteria, one of finfish commodities which can be cultured in acid sulfate medium is snakehead fish Channa striata Bloch.

Snakehead fish is a potential species and has an important value to be developed as an aquaculture commodity (Marimuthu et al., 2009; Mollah et al., 2009; Rahman et al., 2013). This fish has a high economic value with the price in the market ranging $\mathrm{Rp} 55,000-\mathrm{Rp} 65,000 / \mathrm{Kg}$ (Kusumaningrum et al., 2014). Moreover, its flesh is used as a treatment agent for the post-operative therapy and can boost the immunity (Marimuthu et al., 2009).

In managing an aquaculture business, a high production rate is one of the objectives that has to be achieved. One of the external factors that plays an important role for the fish life is the oxygen solubility, because oxygen has an influence on the fish stress response. Beluga Huso huso from two size groups (with average weights of 280.9 $\mathrm{g}$ and $1,217.9 \mathrm{~g})$ reared in the low $(2-3 \mathrm{mg} / \mathrm{L})$, normal $(5-6 \mathrm{mg} / \mathrm{L})$ and high $(9-10 \mathrm{mg} / \mathrm{L})$ oxygen conditions, after eight weeks did not show any significant difference in oxygen consumption among treatments (Lakani et al., 2013). However, there are still many unknown matters about the long-term biological effects that occur when the fish live in the oxygen saturated medium.

The snakehead fish is classified as a fish that is resistant to poor water quality because it has air respiratory organ (diverticula), so this fish is able to take oxygen from the air, but this fish is also sensitive to extreme environmental changes. This fish generally lives in stagnant water (without any water movement) and the water that has no wave. Based on these facts, it is necessary to conduct a study about the survival and growth responses of the snakehead fish juvenile in acid sulfate water medium with and without aeration. This study aimed to analyze the survival response, specific growth, albumin level, feed efficiency, and physiological responses (cortisol, blood glucose, and hemoglobin) of the snakehead fish juvenile reared with and without aeration in acid sulfate water medium.

\section{MATERIALS AND METHODS}

\section{Experimental fish and rearing conditions}

The experimental fish used in this study were the snakehead fish juveniles captured from Kubu Raya West Borneo, sizing $2.4 \pm 0.3 \mathrm{~cm}$ with an average weight of $0.21 \pm 0.03 \mathrm{~g}$. The fish were reared in 24 units of aquarium sizing $30 \times 25 \times 35 \mathrm{~cm}$, with a stocking density of $2 \mathrm{fish} / \mathrm{L}$ (Hidayatullah et al., 2015), filled with the water from a tidal swamp with a salinity of $3.6 \mathrm{~g} / \mathrm{L}$. The tops of aquariums were closed with nets to prevent the fish moving outside of the experimental aquariums. This study was conducted for 40 days, the fish were fed a commercial feed with a protein content of $\pm 40 \%$, twice a day to apparent satiation. Every two weeks, the water replacement was performed by replacing $10 \%$ water of the total water volume in the medium. New water was provided in the reservoir aquarium with the same salinity with the replaced water.

\section{Experimental design}

This study was conducted in the laboratory through a completely randomized design consisting of two treatments; medium equipped with aeration installation and medium without aeration installation. Each treatment applied 12 replicates.

\section{Experimental parameters}

The recording of dead fish data was conducted every day to get the survival data at the end of the study, measurements of the length and the weight of the fish were done every ten days to get the growth data. To determine the amount of the feed consumed was performed by summing the daily feed consumed during the study.

Survival is the percentage of the ratio of the number of the alive fish at the end of the study with the initial number of the fish stocked (Kangombe \& Brown, 2008):

$$
\text { Survival }=(\mathrm{Nt} / \mathrm{No}) \times 100
$$

Note:

Survival $=$ fish survival $(\%)$

$\mathrm{Nt}=$ the number of the fish at the end of the 
study (fish)

No = the number of the fish at the beginning of the study (fish)

Specific growth rate, was calculated using the formula stated by Goddard (1996):

Specific growth rate $(\% /$ day $)=$ $\left[\left(\ln \mathrm{W}_{2}-\ln \mathrm{W}_{1}\right) /\left(\mathrm{T}_{2}-\mathrm{T}_{1}\right)\right] \times 100$

Note:

$\mathrm{SGR}=$ specific growth rate (\%/day)

$\mathrm{W}_{1} \quad=$ the average weigth of the fish at the beginning of the study $\mathrm{T}_{1}(\mathrm{~g})$

$\mathrm{W}_{2} \quad=$ the average weight of the fish at $\mathrm{T}_{2}(\mathrm{~g})$

$\mathrm{T}_{2}-\mathrm{T}_{1}=$ experimental duration

The feed efficiency of the snakehead fish juvenile was calculated using the formula by Kangombe dan Brown (2008):

$$
\mathrm{e}=[((\mathrm{Wt}+\mathrm{D})-\mathrm{Wo}) / \mathrm{F}] \times 100
$$

Note:

$\mathrm{e}=$ feed efficiency

Wo $=$ total weight of the fish at the beginning of the study $(\mathrm{g})$

$\mathrm{Wt}=$ total weight of the fish at the end of the study (g)

$\mathrm{D}=$ total weight of the dead fish during the study $(\mathrm{g})$

$\mathrm{F}=$ total weight of the feed given during the study (g dry weight)

The measurement of albumin level followed the method by Infusino and Panteghini (2013), the proximate analysis of the experimental feed and fish was performed according to the procedure described by Goddard (1996), it was conducted in the Fish Nutrition Laboratory, Department of Aquaculture, Faculty of Fisheries and Marine Science, Bogor Agricultural University. The measurement of hematological parameters (hemoglobin and hematocrit) followed the method by Hastuti and Subandiyono (2011) and was carried out at Zoology Laboratory, while the measurement of plasma glucose level used commercial kit Glucose liquicolor GOD-PAP with calorimetric method and the result was read with a spectrophotometer at a wavelength of 500 $\mathrm{nm}$ following the procedure described by Dinoto et al. (2010), it was conducted at Environmental and Food Technology Laboratory Tanjungpura University, plasma cortisol level was measured by RIA (radio immuno assay) technique using IZOTOP Cortisol [125T] RIA KIT (Ref: RK240CT) following the procedure described by Ramsay et al. (2006), it was conducted at Laboratory of Faculty of Veterinary Medicine Syiah Kuala University, and lactic acid was measured following the method by Wedemeyer and Yasutake (1977) conducted at Laboratory of PT. Saraswanti Indo Genetech Bogor.

Observations and measurements of temperature, $\mathrm{pH}$, dissolved oxygen (DO), and salinity of the water in the mediums were conducted every day, while sulfate $\left(\mathrm{SO}_{4}{ }^{2-}\right)$, sulfide $\left(\mathrm{H}_{2} \mathrm{~S}\right)$, alkalinity, hardness, total ammonia nitrogen, and carbon dioxide $\left(\mathrm{CO}_{2}\right)$ were measured at the beginning and the end of the study.

\section{Statistical analysis}

The data of survival, specific growth, albumin level, feed efficiency, protein retention, energy retention, hemoglobin, hematocrit, cortisol, blood glucose, and lactic acid were analyzed through t-test at confidence level of $95 \%$. Water quality was analyzed using descriptive statistic.

\section{RESULTS AND DISCUSSION \\ Result}

Data from the measurement of the water physical-chemical parameters are presented in Table 1, while data from the measurement of biometric parameters (survival, growth, albumin level, and feed efficiency) and physiological parameters (hemoglobin, hematocrit, cortisol, and blood glucose) of the snakehead fish juvenile reared in the mediums with and without aeration are presented in Table 2 .

Values of water quality parameters of acid sulfate water mediums with a salinity of $3.6 \mathrm{~g} / \mathrm{L}$ used as treatments for the snakehead fish juvenile were quite good. From all parameters observed, only the water temperature was in the optimum range, while the other parameters were only some of those that were in the optimum ranges. However, these average ranges of the water physical-chemical parameters were still quite good for the life of the snakehead fish juvenile, except alkalinity on the treatment with aeration that was in the optimum range (23.00-238.00 $\mathrm{mg} / \mathrm{L} \mathrm{CaCO}_{3}$ ) (Table 1).

Based on the data presented in Table 2, those showed that the lowest cortisol level (21.49 ng/ $\mathrm{mL})$ and blood glucose level $(43.36 \mathrm{mg} / 100$ $\mathrm{mL}$ ) were demonstrated in the treatment without aeration. The highest survival (92\%), specific 
Table 1. The values of the water physical-chemical parameters in each treatment during the study

\begin{tabular}{lccc}
\hline \multicolumn{1}{c}{ Parameters } & \multicolumn{2}{c}{ Treatments } & $\begin{array}{c}\text { Tolerance and } \\
\text { optimum range }\end{array}$ \\
\hline $\mathrm{pH}$ & Aerated medium & Unaerated medium & $4.25-9.4^{* 1)}$ \\
Sulfate $\left(\mathrm{SO}_{4}\right)(\mathrm{mg} / \mathrm{L})$ & $4.5-6.2$ & $4.8-5.8$ & $5-100^{* 2)}$ \\
Sulfide $\left(\mathrm{H}_{2} \mathrm{~S}\right)(\mathrm{mg} / \mathrm{L})$ & $41.00-49.00$ & $46.00-69.00$ & $<0.1^{* 2)}$ \\
Hardness $(\mathrm{mg} / \mathrm{L} \mathrm{CaCO})$ & $0.000-0.005$ & $0.000-0.012$ & $20-150^{* * 3)}$ \\
Alkalinity $(\mathrm{mg} / \mathrm{L} \mathrm{CaCO})$ & $22.00-58.00$ & $26.00-54.00$ & $20-150^{* * 3)}$ \\
Ammonia $(\mathrm{mg} / \mathrm{L})$ & $23.00-238.00$ & $26.00-161.00$ & $<1.57^{* 4)}$ \\
Carbon dioxide $(\mathrm{mg} / \mathrm{L})$ & $0.022-0.037$ & $0.018-0.029$ & $<5^{* 2)}$ \\
Dissolved oxygen $(\mathrm{mg} / \mathrm{L})$ & $0.489-2.056$ & $0.156-1.100$ & $>5^{* * 1)}$ \\
Temperature $\left({ }^{\circ} \mathrm{C}\right)$ & $6.28-6.61$ & $5.42-5.80$ & $26-32^{* 1)}$ \\
\hline
\end{tabular}

Note: ${ }^{1)}$ Astria et al. (2013), ${ }^{2}$ Hartini et al. (2013), ${ }^{3}$ Nisa et al. (2013), and ${ }^{4)}$ Trisna et al. (2013), "tolerance range, **optimum range.

Table 2. Survival, specific growth rate (SGR), albumin level, feed efficiency (FE), protein retention (PR), energy retention (ER), hemoglobin $(\mathrm{Hb})$, hematocrit, cortisol, blood glucose $(\mathrm{BG})$, and lactic acid of the snakehead fish in the treatments during the study

\begin{tabular}{lcc}
\hline \multirow{2}{*}{ Parameter } & \multicolumn{2}{c}{ Treatments } \\
& Aerated medium & Unaerated medium \\
\hline Survival $(\%)$ & $76.00 \pm 4.38 \mathrm{a}$ & $92.00 \pm 4.27 \mathrm{~b}$ \\
SGR $(\% /$ day $)$ & $5.79 \pm 0.90 \mathrm{a}$ & $6.73 \pm 0.62 \mathrm{~b}$ \\
Albumin level $(\mathrm{g} / 100 \mathrm{~mL})$ & $6.12 \pm 0.20 \mathrm{a}$ & $6.60 \pm 0.11 \mathrm{~b}$ \\
FE $(\%)$ & $68.57 \pm 5.20 \mathrm{a}$ & $78.22 \pm 5.53 \mathrm{~b}$ \\
PR $(\%)$ & $28.60 \pm 3.41 \mathrm{a}$ & $41.91 \pm 4.43 \mathrm{~b}$ \\
ER $(\%)$ & $21.69 \pm 2.81 \mathrm{a}$ & $30.81 \pm 3.71 \mathrm{~b}$ \\
Hemoglobin $(\mathrm{g} / \mathrm{dL})$ & $4.92 \pm 0.827 \mathrm{a}$ & $5.85 \pm 0.79 \mathrm{~b}$ \\
Hematocrit $(\%)$ & $24.29 \pm 5.980 \mathrm{a}$ & $28.90 \pm 8.51 \mathrm{a}$ \\
Cortisol $(\mathrm{ng} / \mathrm{mL})$ & $31.17 \pm 2.723 \mathrm{a}$ & $21.49 \pm 1.86 \mathrm{~b}$ \\
BG $(\mathrm{mg} / 100 \mathrm{~mL})$ & $45.45 \pm 0.786 \mathrm{a}$ & $43.36 \pm 1.04 \mathrm{~b}$ \\
Lactic acid $(\mathrm{mg} / \mathrm{L})$ & $6,166 \pm 2093 \mathrm{a}$ & $4,942 \pm 487 \mathrm{a}$ \\
\hline
\end{tabular}

Different letters in the same row indicate significant different results $(\mathrm{P}<0.05)$.

growth rate (6.73\%/day), albumin level (6.60 $\mathrm{g} / 100 \mathrm{~mL}$ ), feed efficiency $(78.22 \%)$, protein retention $(41.91 \%)$, energy retention $(30.81 \%)$, and hemoglobin $(5.85 \mathrm{~g} / \mathrm{dL})$, were shown on the treatment without aeration (Table 2).

\section{Discussion}

The high survival and growth of the snakehead fish on the treatment without aeration was not affected by the water quality conditions of the medium (Extrada et al., 2013). If water quality parameters such as DO, temperature, ammonia, alkalinity, hardness, sulfide, sulfate, and $\mathrm{pH}$ were more than the optimum and tolerance ranges, the fish growth would be inhibited and could cause the fish death.

The dissolved oxygen range during the unaerated medium treatment applied was at a range of 5.42-5.80 mg/L. Dissolved oxygen levels during the study still met the optimum DO range and were not dangerous for the experimental fish, according to Effendi et al. (2012) when the average 
dissolved oxygen level is less than $5 \mathrm{mg} / \mathrm{L}$, it will not cause a death if it does not occur for a long time, because the snakehead fish has a respiratory organ called diverticula, so this fish is able to live in the oxygen depleted water and utilizes oxygen in the air. Because the snakehead fish is classified in the air breathing fish group, so this fish is still alive despite being outside of the treatment medium within a few min to several hours. It is also in line with the statement by Huang et al. (2011), the snakehead fish is able to live in an oxygen depleted area and can tolerate the hypoxic condition. The unaerated medium treatment applied to the snakehead fish had temperature, $\mathrm{NH}_{3}, \mathrm{SO}_{4}^{2-}, \mathrm{pH}$, hardness, and alkalinity ranges observed during the treatment applied (Table 1) that could be tolerated by the snakehead fish to support various metabolic activities and growth (Astria et al., 2013; Hartini et al., 2013; Nisa et al., 2013; Trisna et al., 2013).

The presence of aeration in the experimental medium led to a condition that differed from the natural habitat of the snakehead fish (continuous agitation in the water) and this caused stress responses on the snakehead fish. This was indicated by the high cortisol and blood glucose levels found in the fish reared in the treatment medium with aeration, cortisol level reached $31.17 \mathrm{ng} / \mathrm{mL}$ and blood glucose level reached $45.45 \mathrm{mg} / 100 \mathrm{~mL}$ (Table 2). The increasing of cortisol and blood glucose levels indicated stress condition as a result of the cortisol secretion in the hypothalamus, through the bloodstream to the chromaffin tissue in the kidneys, glucogenesis, and glycogenolysis that eventually increased blood glucose level (Porchase et al., 2009). Due to stress, the fish needs a lot of energy to adapt against stress condition caused by environmental changes. The high energy requirement for survival will stimulate the mobilization of glucose into the blood (Costas et al., 2008; Abdel-Tawwab, 2012). The rearing medium of the snakehead fish juvenile without aeration created a conducive condition for the snakehead fish (stagnant water without agitation), with optimum environmental conditions, the osmoregulation process became minimum and consequently the survival of the snakehead fish would be high. These conditions were demonstrated by the fish reared in the treatment medium without aeration with a cortisol level of $21.49 \mathrm{ng} / \mathrm{mL}$ and a blood glucose level of $43.36 \mathrm{mg} / 100 \mathrm{~mL}$ (Table 2). Cortisol and blood glucose levels were still low compared to those reared in the treatment medium using aeration that had a cortisol level of $31.17 \mathrm{ng} / \mathrm{mL}$ and a blood glucose level of $45.45 \pm 0.786 \mathrm{mg} / 100 \mathrm{~mL}$.

In addition to low cortisol and blood glucose levels, the conditions in the medium without aeration caused a higher hemoglobin content in the blood of the snakehead fish juveniles $(5.85 \mathrm{~g} /$ $\mathrm{dL}$ ) than that on the treatment without aeration (Table 2). The high hemoglobin content indicated that the fish did not suffer anemia because the fish could adapt to the environment (Ramesh \& Saravanan, 2008). The high hemoglobin content also led to a proper availability of oxygen in the tissues, so the metabolic processes were not disrupted. More than $90 \%$ oxygen is carried by hemoglobin derived from oxygen entering through the gill epithelium by diffusion and then binds to hemoglobin in red blood cells contained in the blood capillaries (Johnny et al., 2008). The high oxygen level in the blood affected the physiological response of the fish, that was indicated by a higher survival during the application of the treatment medium without aeration $(92 \%)$, while that on the aerated medium was $76 \%$.

The presence of agitation in the aerated medium made the snakehead fish juvenile becoming more active in movement activities, so that the energy was taken from protein and lipid (Porchase et al., 2009). The fluctuating activity caused the fish requiring energy for its movement, it was shown by the lactic acid values found in this study. The results of t-test presented in Table 2 showed a comparison of lactic acid values that was not significantly different between the aerated medium with a lactic acid value of 4,942 $\mathrm{mg} / \mathrm{L}$ and the unaerated medium with a lactic acid value of $6,166 \mathrm{mg} / \mathrm{L}$. However, the energy requirement for movement activities would be reduced due to the absence of water agitation or flow that stimulated the fish motion.

This condition made the growth of the snakehead fish juvenile reared in the treatment medium without aeration (6.73\%/day) becoming higher compared to the snakehead fish juvenile reared in the aerated medium (5.79\%/day) (Table $2)$. A significant difference $(\mathrm{P}<0.05)$ in the growth rate showed that the snakehead fish reared in the medium without aeration were better in utilizing energy sources obtained from the feed. This could be observed from the feed intake of the experimental fish, the snakehead fish juvenile reared in the medium without aeration consumed the feed with an average amount of 167.80 \pm 47.53 $\mathrm{g}$, this was the highest value compared to that 
on the aerated medium tested in this study $(122.94 \pm 19.33 \mathrm{~g})$. This showed that the aerated medium treatment caused the fish becoming stress and affected the fish appetite.

The high feed intake and the low energy used for osmoregulation would cause the feed converted more to be the fish flesh. This was reflected in the protein retention value in the treatment without aeration that was higher than the treatment with aeration. This indicated that the feed given could be utilized well by the fish body, so that the nutrients contained in the feed could be stored efficiently in the fish body (Porchase et al., 2009). Protein retention is a parameter to indicate the contribution of protein consumed from the diet on the body protein accretion.

In addition to protein retention, the treatment without aeration also showed a higher energy retention value, because the energy that would be used to maintain homeostasi could be minimized, so that the energy could be utilized for the growth. This could be observed from the energy retention value of the snakehead fish juvenile on the treatment without aeration that had an energy retention of $30.81 \%$ that was higher than the treatment using aeration (21.69\%). This happened because the energy produced was secreted in a high amount by the body for metabolism, reproductive activity, biosynthesis, and lost as the heat. According to Subekti et al. (2011), the stored energy is used in the synthesis of cell components and is used as a fuel in the production of the cellular energy.

The results showed that the feed efficiency value of the snakehead fish juvenile reared in the treatment medium without aeration was higher $(78.22 \%)$ compared to those reared in the aerated medium $(68.57 \%)$. The feed utilization efficiency will be optimal when the environmental conditions are in normal conditions, so that the digestion process in the fish digestive tract will be more efficient. This causes the body's cells standing in an ideal condition, so that the physiological processes in the fish body will run normally. The amount of the feed that is able to be consumed by the fish per day is one of the factors that influences the fish potential to grow maximally and the daily feed consumption rate is closely related to the capacity and the emptying of the stomach (Djokosetiyanto et al., 2008).

The albumin level of the fish reared in the treatment medium without aeration also showed a higher level with a value of $6.60 \mathrm{~g} / 100 \mathrm{~mL}$ compared to the albumin level of the fish reared in the aerated medium that was only $6.12 \mathrm{~g} / 100$ $\mathrm{mL}$. This was caused by the unaerated medium conditions causing the fish absorbing more feed nutrients, so the fish could maintain osmotic pressure due to the lack of motion. By maintaining the albumin level in the blood plasma, the fish can maintain the blood volume. According to Infusino and Panteghini (2013), albumin is one of the blood plasma proteins that is synthesized in the liver. Albumin is very important in maintaining the osmotic pressure of the plasma, transporting small molecules to pass through plasma and extracellular fluid (Suprayitno, 2014).

\section{CONCLUSION}

The aerated and unaerated medium gave significant effects on the physiological responses of the snakehead fish juvenile Channa striata Bloch. The treatment medium without aeration resulted in the maximum survival, growth, albumin level, feed efficiency, protein retention, energy retention and hemoglobin, while the cortisol level and the blood glucose level were in the minimum values.

\section{REFERENCES}

Abdel-Tawwab M. 2012. Effects of dietary protein levels and rearing density on growth performance and stress response of Nile tilapia, Oreochromis niloticus L. International Aquatic Research 4: 1-3.

Astria J, Marsi, Fitriani M. 2013. Survival rate and growth of snakehead fish Channa striata on various $\mathrm{pH}$ modification of swamp water mixed with soil substrat. Jurnal Akuakultur Rawa Indonesia 1: 66-75.

Courtenay WR, JR, Williams JD. 2004. Snakeheads Pisces, Channidae: A Biological Synopsis and Risk Assessment. Denver, Colo, USA: US Geological Survey, US Geological Survey Circular.

Costas B, Aragão C, Mancera JM, Dinis MT, Conceição LEC. 2008. High stocking density induces crowding stress and affects amino acid metabolism in Senegalese sole Solea senegalensis (Kaup, 1858) juveniles. Aquaculture Researche 39: 1-9.

Dinoto A, Rahayu RD, Satyaningtijas S. 2010. The change of serum cholesterol level in rats after consuming maltooligosaccharide synthesized by enzimatic reaction of Bacillus licheniformis BL1 amylas. Berita Biologi 10: 
$15-22$.

Djokosetiyanto D, Wulandari AR, Carman O. 2008. The effect of salinity to survival and growth rates on larval rearing of Colossoma macropomum. Jurnal Perikanan 10: 282-289.

Effendi H, Adiwilaga EM, Sinuhaji A. 2012. Pengaruh pencampuran air terhadap oksigen terlarut di sekitar karamba jaring apung, waduk Cirata, Purwakarta, Jawa Barat. Jurnal Ecolab 6: 1-60.

El-Sayeed, Ghobasly AM, Al-Amoda M. 1996. Effects of pond depth and water temperature on the growth, mortality, and body composition of Nile tilapia Oreochromis niloticus. Aquaculture research 27: 681-687.

Extrada E, Ferdinand HT, Yulisman. 2013. Survival and growth rate of snakehead juvenile Channa striata at different levels of water elevation on rearing media. Jurnal Akuakultur Rawa Indonesia 1: 103-114.

Goddard S. 1996. Feed Management in Intensive Aquaculture. New York (US): Chapman and Hall.

Hartini S, Sasanti AD, Taqwa FH. 2013. Water quality, survival rate and growth of snakehead Channa striata maintained in media with addition of probiotics. Jurnal Akuakultur Rawa Indonesia 1: 192-202.

Hastuti S, Subandiyono. 2011. Hematological performances of catfish 'sangkuriang' Clarias gariepinus Burch. fed on deits containing organic chromium. Jurnal Saintek Perikanan 7: 56-62.

Hidayatullah S, Muslim, Taqwa FH. 2015. Rearing of snakehead Channa striata in plastic lined pond with different stocking density. Jurnal Perikanan dan Kelautan 20: 61-70.

Huang CY, Lin CP, Lin HC. 2011. Morphological and biochemical variations in the gills of 12 aquatic air-breathing anabantoid fish. Physiological and Biochemical Zoology 84: 125-134.

Infusino I, Panteghini M. 2013. Serum albumin: accuracy and clinical use. Clinica Chimica Acta 419: 15-18.

Johnny F, Zafran, Rosa D, Mahardika K. 2008. Hematologis beberapa spesies ikan laut budidaya. Jurnal Penelitian Perikanan Indonesia 9: 63-71.

Kangombe J, Brown JA. 2008. Effect of Salinity on growth, feed utilization, and survival of Tilapia rendalli under laboratory conditions. Journal Appliance Aquaculture 20: 256-271.

Kusumaningrum GA, Alamsjah MA, Masithah
ED. 2014. Albumin level test and snakehead fish Channa striata growth with different commercial feed protein level. Jurnal Ilmiah Perikanan dan Kelautan 6: 25-29.

Lakani BF, Sattari M, Falahatkar B. 2013. Effect of different oxygen levels on growth performance, stress response and oxygen consumption in two weight groups of great sturgeon Huso huso. Iranian Journal of Fisheries Sciences 12: 533-549.

Marimuthu K, Arokiara JJ, Haniffa MA. 2009. Effect of diet quality on seed production of the spotted snakehead Channa punctatus (Bloch). American-Eurasian Journal of Sustainable Agriculture 3: 344-347.

Mollah MFA, Mamun MSA, Sarowar MN, Roy A. 2009. Effects of stocking density on the growth and breeding performance of broodfish and larval growth and survival of shol Channa striatus Bloch. Journal of the Bangladesh Agricultural University 7: 427-432.

Nisa K, Marsi, Fitriani M. 2013. The effect of swamp water $\mathrm{pH}$ on survival rate and growth of fry snakehead fish Channa striata. Jurnal Akuakultur Rawa Indonesia $1:$ 57-65.

Rahman MA, Arshad A, Amin SMN, Shamsudin MN. 2013. Growth and survival of fingerling of a threatened snakehead Channa striatus (Bloch) in earthen nursery ponds. Asian Journal of Animal and Veterinary Advances 8: 216-226.

Ramesh M, Saravanan M. 2008. Haematological and biochemical responses in a freshwater fish Cyprinus carpio exposed to chlorpyrifos. International Journal of Integrative Biology 3: 80-83.

Ramsay JM, Feist GW, Varga ZM, Westerfield M, Kent ML, Schreek CB. 2006. Whole-body cortisol is an indicator of crowding stress in adult zabra fish Danio rerio. Aquaculture 258: 565-574.

Porchase MM, Luis R, Martinez C, Enriquez R, Rogelio. 2009. Cortisol and glucose: reliable indicators of fish stress. American Journal of Aquatic Sciences 4: 158-178.

Lantu S. 2010. Osmoregulation in aquatic animals. Jurnal Perikanan dan Kelautan 6: 46-50.

Subekti S, Prawesti M, Arief M. 2011. Pengaruh kombinasi pakan buatan dan pakan alami cacing sutera Tubifex tubifex dengan persentase yang berbeda terhadap retensi protein, lemak, dan energi pada ikan sidat Anguilla bicolor. Jurnal Kelautan 4: 90-95. 
Suprayitno E. 2014. Profile albumin fish cork Ophicephalus striatus of different ecosystems. International Journal Current Research Academic Review 2: 201-208.

Trisna DE, Sasanti AD, Muslim. 2013. Population bacteria, water quality of media maintenance, and histology of snakehead Channa striata fry feeding by artificial feed with probiotic. Jurnal Akuakultur Rawa Indonesia 1: 90-102.

Wedemeyer GA, Yasutake WT. 1977. Clinical methods for the assessment of the effect on environmental stress on fish health. Fish and Wildlife Service 89: 1-17. 